\title{
Impact of solid waste on water quality of Bishnumati River and surrounding areas in Kathmandu, Nepal
}

\author{
*Dinesh C. Devkota ${ }^{l}$ and Kunio Watanabe ${ }^{2}$ \\ ${ }^{1}$ Graduate School of Science and Engineering, Saitama University, \\ 255 Shimo - Okubo, Sakura-ku, Saitama City, Saitama ken 338 -8570, Japan \\ ${ }^{2}$ Geosphere Research Institute, Saitama University, \\ 255 Shimo - Okubo, Sakura-ku, Saitama ken 338 -8570, Japan \\ (*Email:ddgorkha@hotmail.com)
}

\begin{abstract}
Haphazard dumping of solid waste on the banks of the Bishnumati River in the Kathmandu valley has severely deteriorated the surface and subsurface water quality. The river water as well as shallow wells in the vicinity exhibited very high conductivity as well as high nitrate, nitrite, and COD concentrations. Though the water in the shallow wells is not potable, it is being used by the inhabitants. Improper waste management has caused environmental pollution, increased public health hazard, and adversely impacted on urban economy.
\end{abstract}

\section{INTRODUCTION}

Solid waste is one of the by-products of human activities. The introduction of new materials, changing consumption patterns, and increasing waste generation, especially in urban areas, have contributed to the problems of waste management. In Nepal, as in many other developing countries, these problems have escalated rapidly over the past few decades, while the government and people have failed to realise their serious implications and an urgent need to address them. As a result, Nepal, and especially the Kathmandu valley (with Kathmandu, Bhaktapur, and Lalitpur municipalities), is now suffering from the adverse impact of unmanaged waste. Improper management of waste has led to environmental pollution, public health hazard, and adverse effects on an urban economy that depends heavily on touris $m$

In Nepal, only a few organisations are presently involved in solid waste management. The persistence of traditional attitudes and traditional waste disposal habits in both residential and industrial areas as well as a lack of commitment to deal with this issue by the governmental, nongovernmental, and private organisations is hindering the efforts to collect and dispose wastes in an effective and environmentally safe manner (Devkota et al. 2003).

A huge amount of waste has been dumped on the banks of the Bishnumati River, which is one of the tributaries to the Bagmati River. The uncontrolled dumping has severely contaminated the groundwater as well as river water. Hence, in this study an attempt was made to carry out systematic water quality monitoring of the Bishnumati River.

This paper deals with the impact of solid waste on the Bishnumati River and adjacent dug wells and tubewells. The quality of shallow groundwater and leachate in the vicinity of dumping site was analysed by a number of institutions in the past. For the purpose of comparing the past data and extrapolating their trends, the quality of river water, shallow wells, and leachate was tested in May 2004.

\section{STUDYAREA}

The study area is located within the Kathmandu valley, one of the most densely populated intermontane basins in the Himalaya (Fig. 1). The oval-shaped Kathmandu valley extends for about $30 \mathrm{~km}$ in the east-west and $25 \mathrm{~km}$ in the north-south directions. It occupies an area of about 650 sq $\mathrm{km}$ and ranges in altitude from 1220 to $1500 \mathrm{~m}$.

The Bishnumati River has a great religious significance, as many famous temples are situated on its banks. The river has been used for bathing and other religious purposes since the early days of settlement in the valley. The river flows between the altitudes of $2,481 \mathrm{~m}$ (the origin in the Shivapuri hills) and 1,289 $\mathrm{m}$ (confluence with the Bagmati River at Teku). In this stretch, it is 65-100 m wide. The recorded mean monthly flow of this river at Teku is $0.72 \mathrm{~m}^{3} / \mathrm{sec}$ in March (minimum) and $16.62 \mathrm{~m}^{3} / \mathrm{sec}$ in August (maximum). The total catchment area of this river upstream of its confluence with the Bagmati River is about $80 \mathrm{sq} \mathrm{km}$ (Karki 2002).

The banks of the Bishnumati River have become provisional landfill sites, where dumping of solid waste from Kathmandu was started in 1994. The dumping zone extends from Balaju in the northwestern part of the metropolis to Teku, at the confluence with the Bagmati River (Fig. 2). 


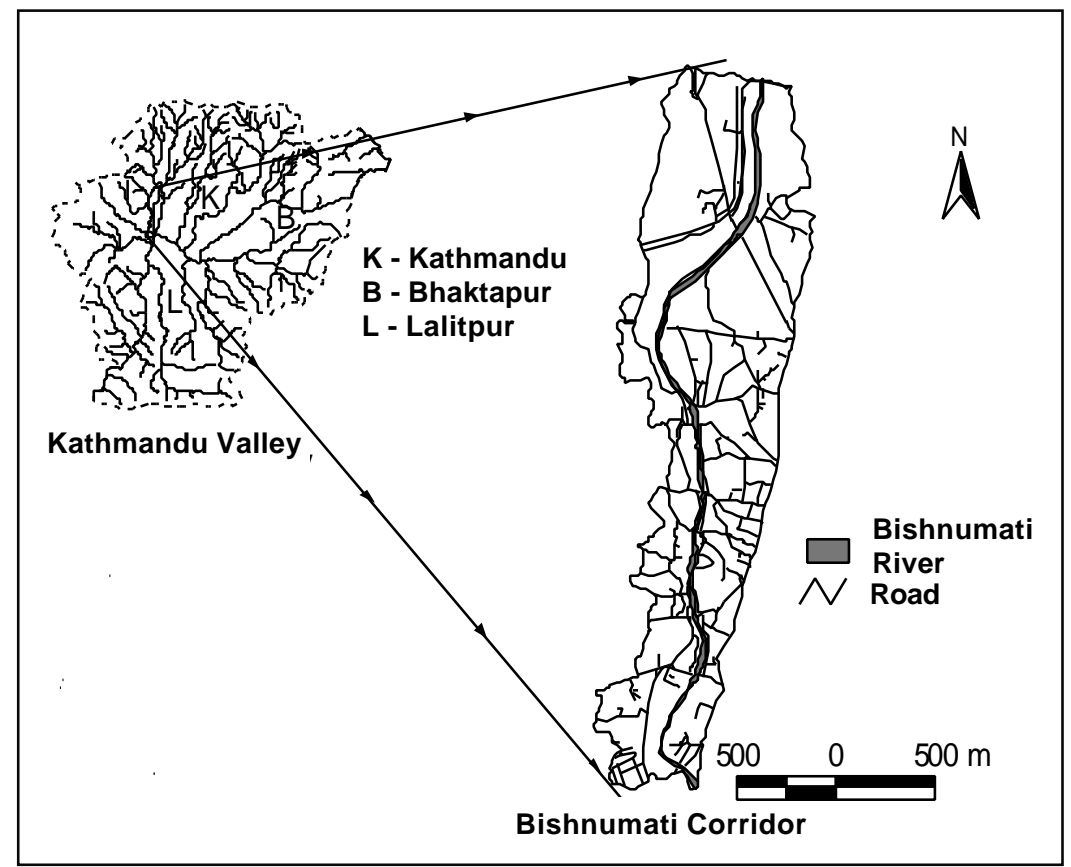

Fig. 1: Location map of the study area

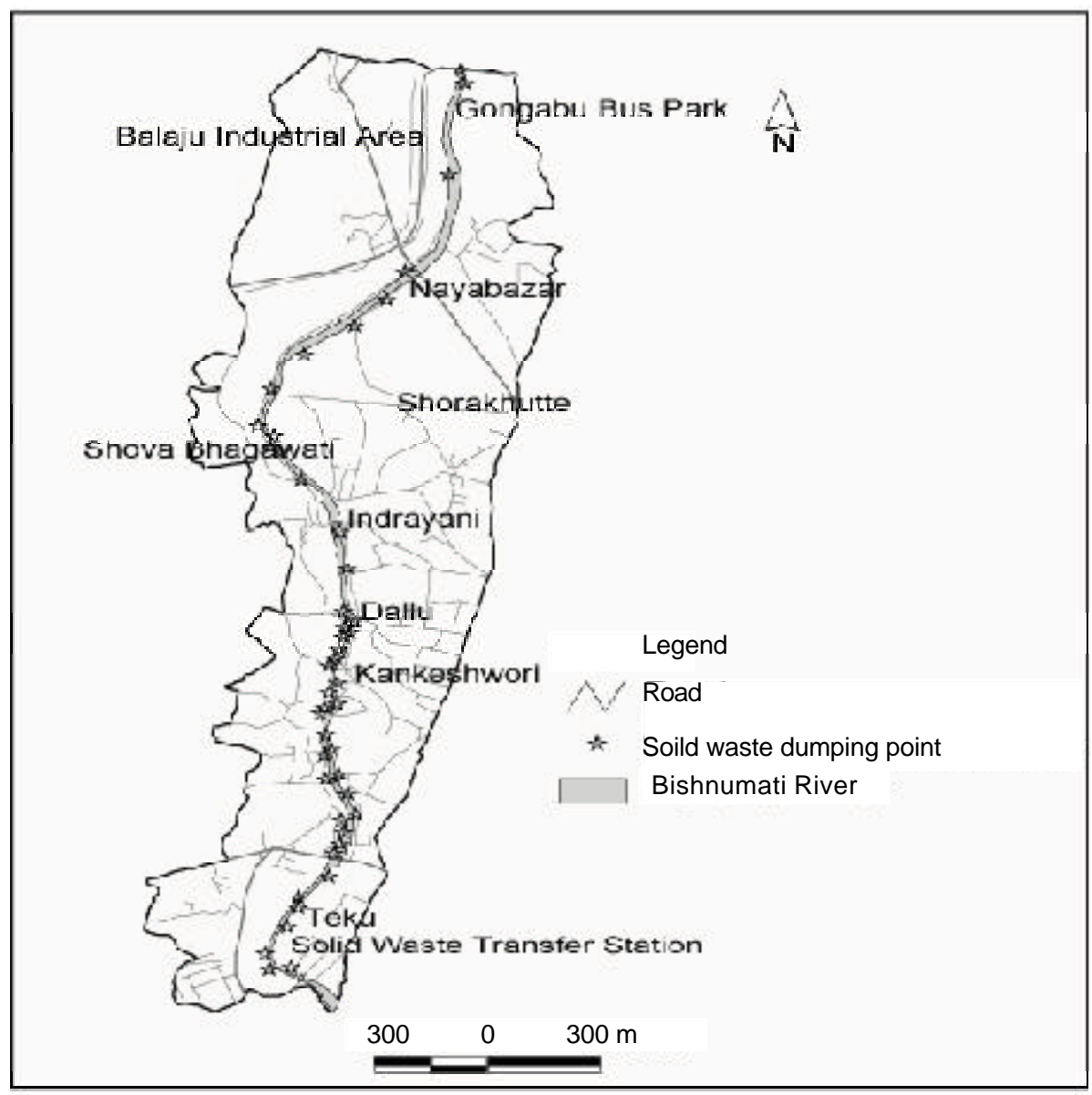

Fig. 2: Solid waste dumping sites on the Bishnumati River banks 


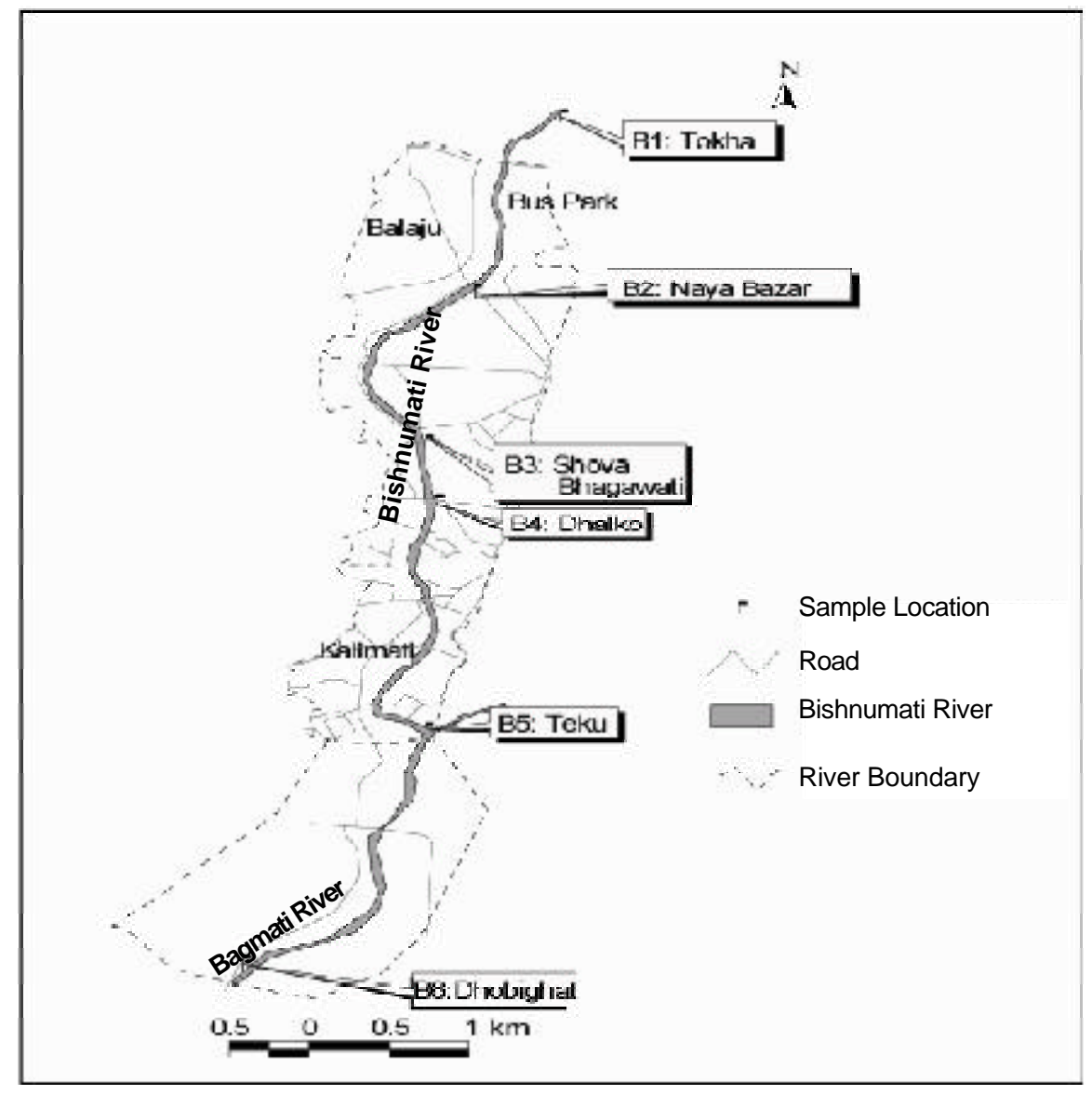

Fig. 3: Water sampling sites in the Bishnumati and Bagmati Rivers

\section{DUMPING SITE}

Owing to the lack of a regular disposal site, the municipality has been disposing of the solid wastes on the banks of the Bishnumati and Bagmati Rivers for more than ten years. Haphazard dumping of solid waste continues from the Bishnumati River to the Bagmati River and reached up to Dhobighat (Fig. 3). The solid waste has been dumped on the floodplain or buried without considering its adverse impact on groundwater. The thickness of waste varies from 3 to $4 \mathrm{~m}$ and width ranges from 10 to $50 \mathrm{~m}$ as per the site conditions. There are no protection works against river erosion and the leachate is flowing directly into the river.

The common filling technique at the landfill is the spreading of garbage on the ground followed by its compaction and covering by a thin layer of clay, cobble, and pebble. Spreading of solid waste is done daily, but compression and covering is carried out once or twice a week (Fig. 4a). To prevent flies and other pests from breeding, sometimes lime powder is sprinkled on the surface of the refuse. The process of land filling is not preventing the disease vector or the production of bad odour. Stray animals and birds are seen scavenging the garbage littering the locality. When there is a thick layer of solid waste, it is converted into a gravelled road (Fig. 4b).

There are many other reasons for the deterioration of water quality in the Bishnumati River. The deterioration may also be attributed to the excessive disposal of polluted water into the river. Most of industries (except for a few that have their own preliminary water treatment plant) dispose wastewater into the river without prior treatment. Furthermore, the slaughterhouses located along the banks of the Bishnumati River also dispose of the waste directly into the river (Shakya 2001)

\section{SAMPLINGAND ANALYSIS}

Water samples were collected from six locations and included shallow wells, surface water, and leachate. The samples spread from Tokha (B1) in the north to Dhobighat (B6) in the south (Fig. 3).

A total of nineteen parameters were analysed and they included physical, chemical, and microbiological indicators . These parameters were selected specifically to look into the heavy metal concentration and other chemical content in the leachate and surrounding waters. 


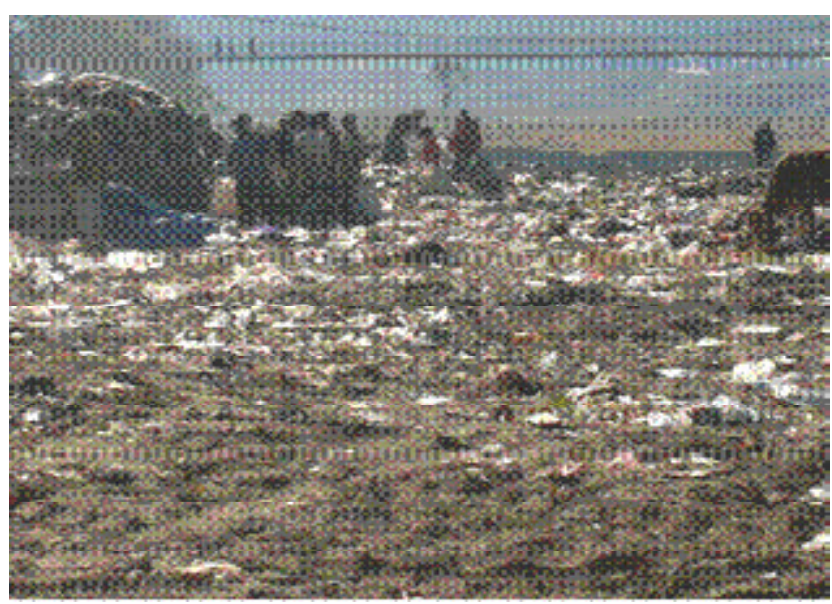

Fig. 4a: Solid waste disposal at B6 (see Fig. 3); Note the dump under the suspension bridge, March 2004.

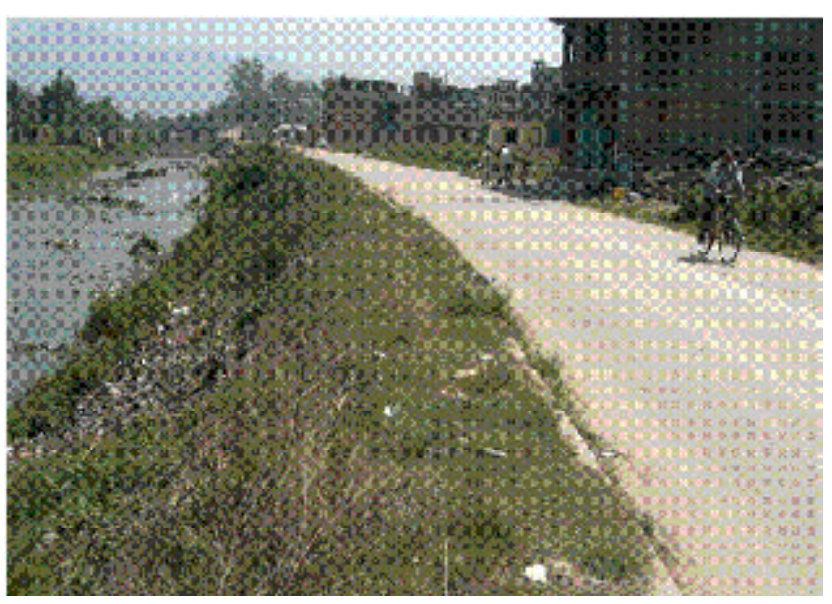

Fig. 4b: Road constructed on the solid waste near B3 (see Fig. 3 for location), March 2004

Table 1: Results of water quality analysis carried out in May 2004

\begin{tabular}{|c|c|c|c|c|}
\hline Locality & Tokha & Naya Bazaar & Dhalko & Dhobighat \\
\hline Sample location & B1 & B2 & B4 & B6 \\
\hline Source & Tubewell & Tubewell & Tubewell & Dug well \\
\hline Sample depth, $m$ & 5.49 & 6.71 & 3.66 & 3.35 \\
\hline \multirow{2}{*}{ Coordinate } & $27^{\circ} 40^{\prime} 23.3^{\prime \prime} \mathrm{N}$ & $27^{\circ} 43^{\prime} 25.8^{\prime \prime} \mathrm{N}$ & $27^{\circ} 42^{\prime} 42.7^{\prime \prime} \mathrm{N}$ & $27^{\circ} 40^{\prime \prime} 28.6^{\prime \prime} \mathrm{N}$ \\
\hline & $85^{\circ} 18^{\prime} 45.2^{\prime \prime} \mathrm{E}$ & $85^{\circ} 18^{\prime} 14.2^{\prime \prime} \mathrm{E}$ & $85^{\circ} 18^{\prime} 10.4^{\prime \prime} \mathrm{E}$ & $85^{\circ} 17^{\prime} 42^{\prime \prime} \mathrm{E}$ \\
\hline Altitude & $1336 \mathrm{~m}$ & $1283 \mathrm{~m}$ & $1311 \mathrm{~m}$ & $1266 \mathrm{~m}$ \\
\hline \multicolumn{5}{|l|}{ Parameters } \\
\hline Temperature $\left({ }^{\circ} \mathrm{C}\right)$ & 19.00 & 19.2 & 20.2 .0 & 20.40 \\
\hline $\mathrm{pH}$ & 6.4 & 6.4 & 6.50 & 6.60 \\
\hline Conductivity $(\mu \mathrm{S} / \mathrm{cm})$ & 521.00 & 807.0 & 1009.00 & 842.00 \\
\hline Ammonia (mg/l) & 1.60 & 4.5 & 3.00 & 6.80 \\
\hline Nitrite $(\mathrm{mg} / \mathrm{l})$ & 0.12 & 0.542 & 1.00 & 1.07 \\
\hline Nitrate $(\mathrm{mg} / \mathrm{l})$ & 0.13 & 0.725 & 0.20 & 0.81 \\
\hline Phosphate $(\mathrm{mg} / \mathrm{l})$ & 0.03 & 0.024 & 0.02 & 0.196 \\
\hline Iron $(\mathrm{mg} / \mathrm{l})$ & 2.54 & 1.74 & 2.33 & 1.07 \\
\hline Manganese (mg/l) & 0.40 & 0.06 & 0.51 & 0.88 \\
\hline Nickel (mg/l) & 0.01 & 0.018 & 0.015 & 0.016 \\
\hline Copper (mg/l) & $<0.01$ & 0.14 & $<0.01$ & $<0.01$ \\
\hline Zinc (mg/l) & 0.13 & 0.25 & 0.10 & 0.16 \\
\hline Chromium (mg/l) & $<0.01$ & $<0.01$ & $<0.01$ & $<0.01$ \\
\hline Cadmium (mg/l) & 0.0012 & 0.0017 & $<0.001$ & 0.0013 \\
\hline
\end{tabular}

Samples B1, B2, B4, and B6 were collected from tubewells or dug wells. B3 was the leachate source, whereas B5 was collected fromthe river. The depth of water tablein the shallow wells varied from 3.35 to $6.71 \mathrm{~m}$ during sampling.

Parameters like temperature, $\mathrm{pH}$, and conductivity were measured in the field, while other chemical parameters were analysed at the laboratories of Royal Nepal Academy of Science and Technology (RONAST) and Institute of Engineering, Tribhuvan University (IOE, TU), Nepal. Heavy metals were analysed using Atomic Absorption Spectrophotometer (AAS). For other parameters, the procedure described by Lenore et al. (1998) was followed.

\section{RESULTS AND DISCUSSIONS}

The samples from shallow wells (B1, B2, B4, and B6), river water(B5), and leachate (B3) were analysed to see the trend and to assess the level of pollution. The leachate and river water values were compared with the past data of Sharma et al. (1995) and the level of pollution was assessed, whereas the shallow wells were compared with each other for trend analysis of pollution level. The samples from shallow wells were also compared with the World Health Organisation (WHO) guideline values for drinking water because the shallow wells are the major water sources for the dwellers for daily usage. Table 1 presents the analysis results of May 2004 samples, including 


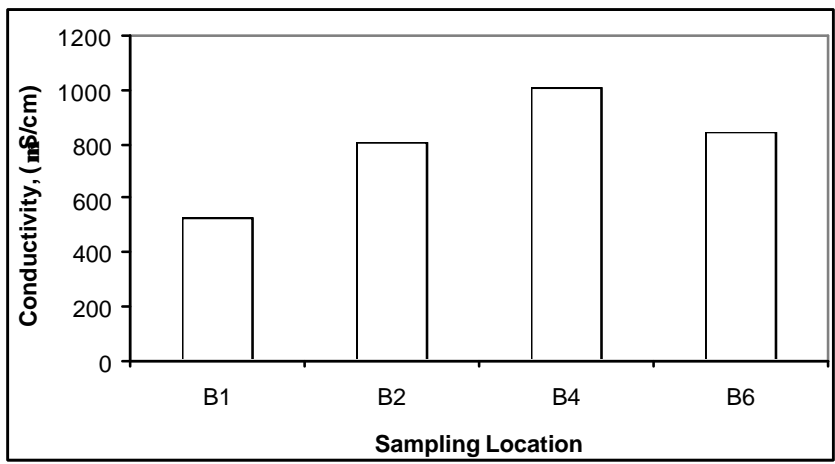

Fig. 5a: Conductivity in shallow wells

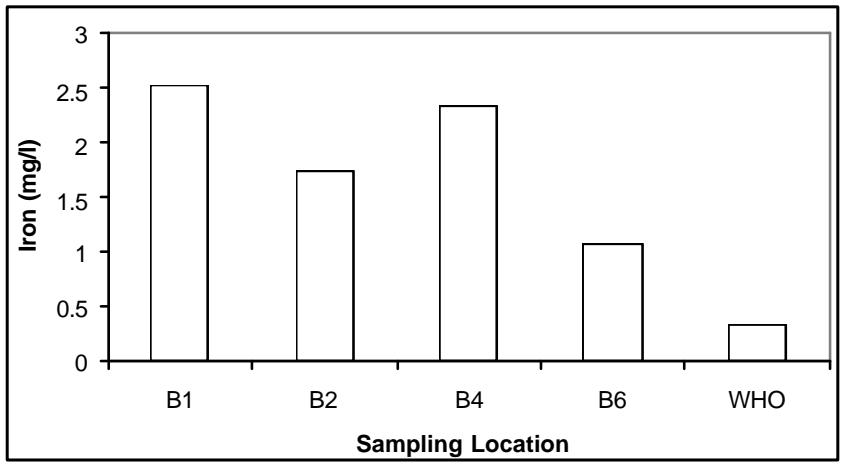

Fig. 5c: Iron concentration in shallow wells

Table 2: Comparison of different parameters of the Bishnumati River water

\begin{tabular}{l|r|r|r}
\hline \multicolumn{1}{c|}{ Parameter } & $\begin{array}{c}\text { Downstream } \\
\mathbf{1 9 9 4}\end{array}$ & $\begin{array}{c}\text { Downstream } \\
\text { 2004 (B5) }\end{array}$ & \multicolumn{1}{c}{$\begin{array}{c}\text { Upstream } \\
\mathbf{1 9 9 4}\end{array}$} \\
\hline $\mathrm{pH}$ & 7.27 & 7.7 & 7.39 \\
\hline $\begin{array}{l}\text { Conductivity, } \\
(\mu \mathrm{S} / \mathrm{cm})\end{array}$ & 168 & 10020 & 154 \\
\hline Nitrate, $\mathrm{mg} / \mathrm{l}$ & 0.31 & 5 & 0.25 \\
\hline Nitrite, $\mathrm{mg} / \mathrm{l}$ & 0.12 & 0.3 & 0.14 \\
\hline COD, $\mathrm{mg} / \mathrm{l}$ & 10.6 & 75.46 & 4.7 \\
\hline Phosphate, $\mathrm{mg} / \mathrm{l}$ & 0.18 & 24.2 & 0.22 \\
\hline Copper, $\mathrm{mg} / \mathrm{l}$ & $<0.005$ & 0.03 & $<0.005$ \\
\hline Iron, $\mathrm{mg} / \mathrm{l}$ & 1.97 & 1.8 & 1.38 \\
\hline Manganese, $\mathrm{mg} / \mathrm{l}$ & 0.23 & 0.47 & 0.21 \\
\hline Lead, $\mathrm{mg} / \mathrm{l}$ & $<0.005$ & 0.026 & 0.01 \\
\hline Cadmium, $\mathrm{mg} / \mathrm{l}$ & $<0.005$ & 0.001 & 0.005 \\
\hline Chromium, mg/l & 0.05 & $<0.01$ & $<0.01$ \\
\hline Nickel, $\mathrm{mg} / \mathrm{l}$ & 0.01 & 0.027 & $<0.1$ \\
\hline Zinc, $\mathrm{mg} / \mathrm{l}$ & 0.09 & 0.15 & 0.1 \\
\hline
\end{tabular}

their position, location, and depth. A comparison of theirvalues with those of Sharma et al. (1995) indicates that the impact of disposal waste is very pronounced both in the shallow wells and the river.

The conductivity of shallow well water increases from north to south. Its highest value was recorded in the shallow well of B4, situated in the lower reach of the Bishnumati River (Fig. 5a).

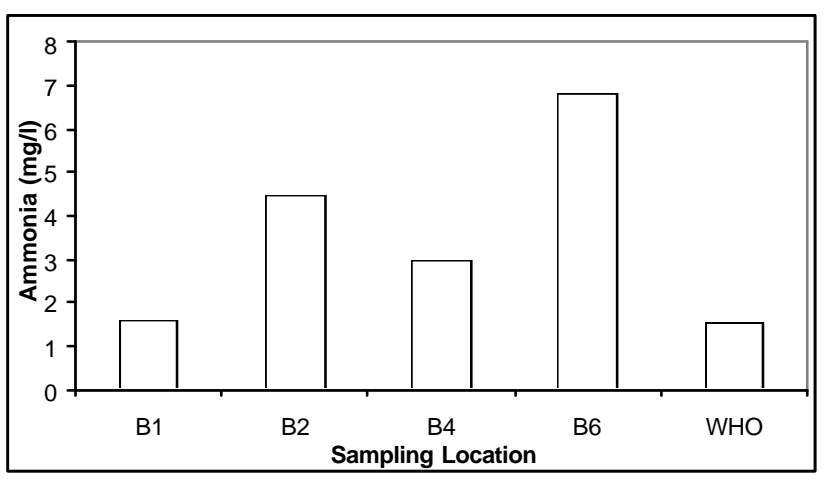

Fig. 5b: Ammonia concentration in shallow wells

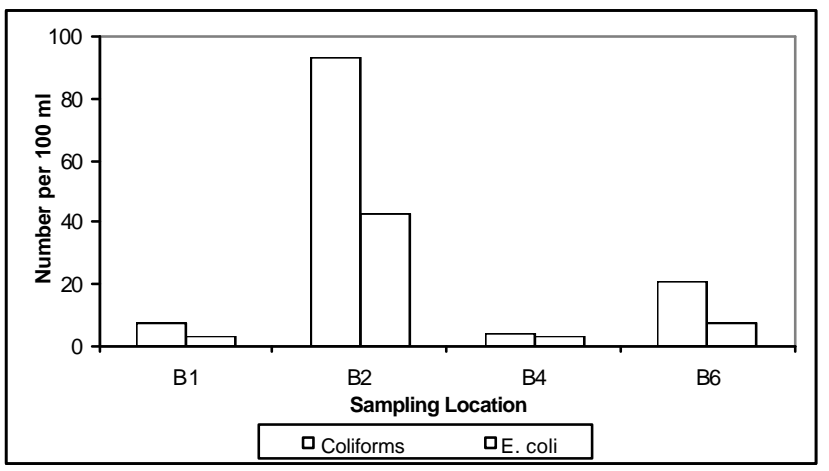

Fig. 5d: Microbial contamination in shallow wells

The ammonia concentration of all the shallow wells is higher than the WHO guideline value of $0.5 \mathrm{mg} / \mathrm{l}$ (WHO 1993) with the highest being at Dhobighat (B6). It indicates that the tubewells are highly contaminated by organic wastes (Fig. 5b).

The concentration of heavy metals is within the WHO guideline values except for iron and manganese. For all the samples of wells, the iron concentration is higher, while the concentration of manganese for the well at B6 is slightly higher than the WHO guideline value (Fig. 5c).

All the well waters contain microbial contamination and they are unsafe for drinking without prior treatment (Fig. 5d). The highest concentration of coliform and E. coli (i.e., 42/ml) was found in B2.

\section{Surface water quality assessment}

Surface water samples were collected only from the lower reach at Teku (B5), where the waste load was considered to be higher than that in other parts of the Bishnumati River. A comparison with the earlier data (Sharma et al. 1995) indicates that the river water pollution has increased considerably since the last decade (Table 2).

The quality of river water was measured upstream and downstream of the landfill site of Teku in 1994 and 2004. Conductivity, COD as well as nitrate and nitrite concentrations were found slightly higher in the downstream areas than in the upstream areas in 1994. But, their difference 


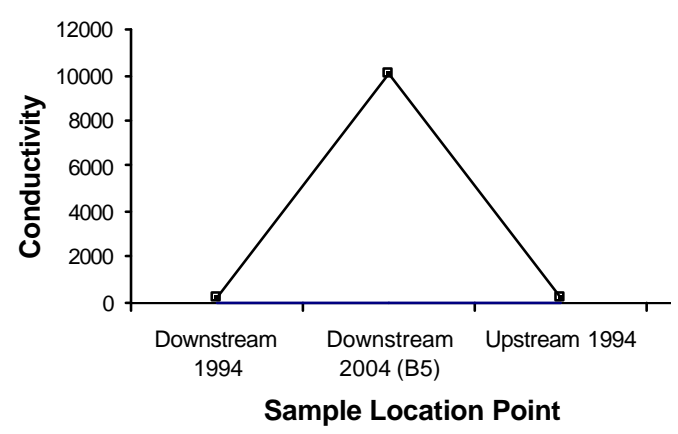

Fig. 6a: Comparison of conductivity of the Bishnumati River

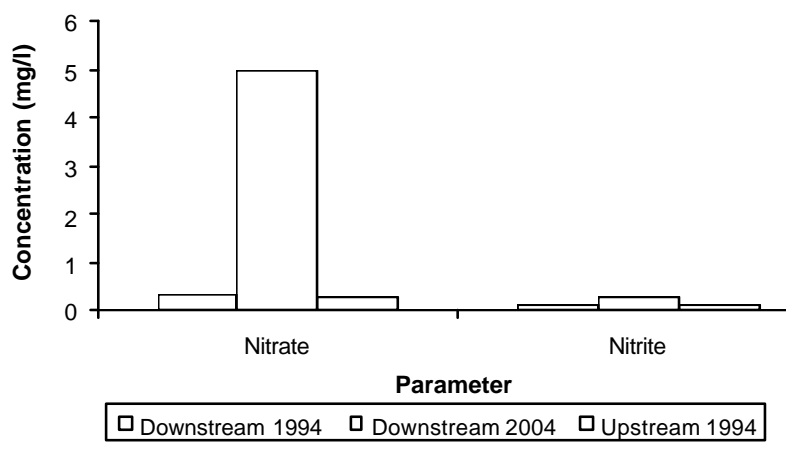

Fig. 6c: Comparisons of nitrate and nitrite of Bishnumati River

became more prominent in 2004, indicating an increase in solid waste load at the landfill site (Fig. 6a, b, c).

\section{Leachate assessment}

The leachate samples collected at Shova Bhagawati (B3) in 2004 recorded significantly higher values of conductivity, COD, nitrate, phosphate, and heavy metal concentrations (Table 3) compared to the values recorded by Sharma et al. (1995) (L1, L2, L3, and L4).

\section{CONCLUSIONS}

The analysed samples indicate that the pollution level has increased significantly in the downstream areas. The conductivity of water from shallow wells increases gradually towards the south, indicating an increase in ionic concentration. Since none of the samples are free of pollution (mainly microbial contamination), the water requires treatment before using for drinking purpose. Similarly, a comparison of the leachate sampled in 1994 with that of 2004 showed an increase in the values of conductivity, COD, and nitrate as well as the concentration of phosphate and heavy metals.

\section{ACKNOWLEDGEMENTS}

We thank RONAST and IOE (TU) for providing lab facilities. Thanks are due to SWMRMC, BCDA, and Ms. Anu Sharma (IDS-Nepal) for their co-operation.

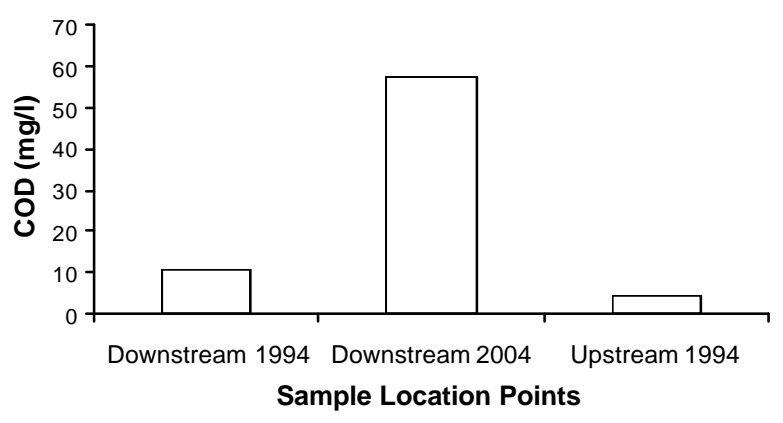

Fig. 6 b: Comparison of COD of the Bishnumati River

Table 3: Comparison of leachate of 1994 and 2004

\begin{tabular}{l|c|c|c|c|c}
\hline \multirow{2}{*}{ Parameters } & \multicolumn{4}{|c|}{$\begin{array}{c}\text { 1994, Leachate at } \\
\text { different location points }\end{array}$} & $\begin{array}{c}\text { 2004, } \\
\text { Shova } \\
\text { Bhagabati }\end{array}$ \\
\cline { 2 - 6 } & L1 & L2 & L3 & L4 & $($ B3) \\
\hline pH & 7.53 & 6.82 & 7.2 & 8.01 & 7.5 \\
\hline Conductivity & & & & & \\
\hline Nitrate, mg/l & 8790 & 1291 & 229 & 780 & 40930 \\
\hline Nitrite, mg/l & 2.7 & 0.35 & 0.31 & 11.86 & 3.25 \\
\hline COD, mg/l & 0.02 & 0.03 & 0.1 & 2.25 & $<0.02$ \\
\hline Phosphate, mg/l & 3205 & 517.4 & 18.8 & 28.2 & 811.5 \\
\hline Copper, mg/l & 0.3 & 0.16 & 0.1 & 0.3 & 8.6 \\
\hline Iron, mg/l & 0.14 & 0.01 & $<0.005$ & $<0.005$ & 0.042 \\
\hline Manganese, mg/l & 9.1 & 8.4 & 2.58 & 0.2 & 1.9 \\
\hline Lead, mg/l & 3.8 & 2.5 & 0.3 & 0.1 & 0.42 \\
\hline Cadmium, mg/l & 0.28 & 0.03 & $<0.005$ & $<0.005$ & 0.015 \\
\hline Chromium, mg/l & 1.06 & 0.2 & 9.09 & 0.09 & 0.017 \\
\hline Nickel, mg/l & 0.13 & $<0.01$ & $<0.01$ & $<0.01$ & 0.04 \\
\hline Zinc, mg/l & 0.65 & 0.11 & 0.06 & 0.06 & 0.23 \\
\hline
\end{tabular}

Source: Sharma et al. (1995) and Devkota (2004)

\section{REFERENCES}

Devkota, D. C, Watanabe, K., and Dangol, V., 2003, Solid Waste Management Issues in Nepal-Gokarna Landfill Site and its Impact on Groundwater. Proceeding on Seminar of Solid Waste Issue: An Environmental Problem organised by TU, Nepal and GRIS, Saitama University, Japan, pp 47-57.

Karki, J. B, 2002, Environmental Baseline of Bishnumati Corridor, A Report submitted to World Vision Nepal, Community Led Environmental Action Network (CLEAN, NEPAL), Kathmandu.

Lenore S. C., Arnold E. G., and Andrew D. E. (Editors), 1998, Standard Methods for the Examination of Water and Wastewater (20th Edition). Published by the American Public Health Association, the American Water Works Association and the Water Environment Federation, $1220 \mathrm{p}$.

Shakya, S. K, 2001, Alarming Trends of River Pollution in Kathmandu, Nepal. J. Environment, v. VI, pp. 96-109.

Sharma, T., Upadhyaya, N. P., and Shahi, K., B, 1995, Leachate Characteristics: Bishnumati Landfill Site, Kathmandu. J. ENVIRONMENT, Nepal Environmental and Scientific Services (P) Ltd. Thapathali, Kathmandu. pp. 52-58.

WHO, 1993, Guidelines for Drinking Water Quality. v. II, World Heath Organisation. 